\title{
Solute Movement Patterns in Trickle Irrigated Tomatoes $^{1}$
}

\author{
Megh R. Goyal, Victor A. Snyder, and Luis E. Rivera ${ }^{2}$
}

\begin{abstract}
A study was conducted in a commercial drip irrigated tomato (var. Floradel) field to investigate fertilizer solute movement patterns in relation to dripper location. Six to nato plots were established, three of which were planted and the other three left fallow. Soil samples were taken at planting and after harvest at various locations from the dripper and were analyzed for electrical conductivity, $\mathrm{pH}$, bicarbonate-extractable $\mathrm{P}$, and ammonium acetate-extractable (IN, pH 7), $\mathrm{K}, \mathrm{Na}, \mathrm{Ca}$, and $\mathrm{Mg}$. All fertilizer was applied via drip irrigation. Considerable movement of $\mathrm{P}$ was observed throughout the soil profile possibly because of slow rates of calcium phosphate precipitation due to the low pH of the irrigation water and the possible presence of $\mathrm{Mg}^{+2}$ and $\mathrm{HCO}_{3}{ }^{-1}$ in solution, and to the predominant movement of fertilizer solutions through soil macropores. Movement of $\mathrm{K}$ was less evident than that of $\mathrm{P}$, but could have been masked by large plant uptake of $\mathrm{K}$. Increases in electrical conductivity were most evident near the emitter and along the salt fringe at the edge of the wetting zone near the soil surface. Conductivity increased most in the latter zone, but never exceeded $0.8 \mathrm{mmhos} / \mathrm{cm}$. Levels of $\mathrm{P}, \mathrm{K}$, and electrical conductivity at the end of the experiment were nearly always larger in the fallow plots than in the tomato plots, probably because of nutrient uptake by the tomato root system in the latter.
\end{abstract}

\section{INTRODUCTION}

Among the advantages of using drip irrigation for crop production is that soluble fertilizer may be applied. Efficient use of drip-applied fertilizer requires an understanding of nutrient uptake by plants and solute movement patterns in the soil. Such data is scarce for Puerto Rico. Keng (5) compared banded and broadcast $\mathrm{N}$ and $\mathrm{K}$ with application via drip irrigation in Coto clay, an Oxisol occurring in northwestern Puerto Rico. His data suggested significant lateral and vertical movement of $\mathrm{N}$ and $\mathrm{K}$ within the soil profile. Laboratory column studies on Coto clay and Piña sand, both Oxisols, indicated low mobility of $\mathrm{P}$ in Coto clay, but relatively high mobility in Piña sand. The higher clay content and lower silica:sesquioxide ratio in Coto clay probably resulted in significantly greater $\mathrm{P}$ adsorption (4), and hence lower mobility.

Most commercial use of drip irrigation in Puerto Rico is currently found on vegetable farms in the southern coast of the island. The clay

${ }^{1}$ Manuscript submitted to Editorial Board November 3, 1982.

${ }^{2}$ Assistant Agricultural Engineer, Assistant Professor of Soil Science and Scientific Research Technician, Agricultural Experiment Station, University of Puerto Rico, Mayagüez Campus, Rio Piedras. Authors thank Fernando Abruña, USDA-SEA, José Vicente Chandler, USDA-SEA, Miguel Lugo López, Soil Scientist, and Raúl Pérez Escolar, Soil Scientist for their constructive criticisms. Use of facilities at ISPRAC Farm is fully acknowledged. 
fraction in these soils is largely of the $2: 1$ type, which generally results in higher cation exchange capacity and lower P-fixation tendency than in Oxisols, in which the dominant clays are 1:1 minerals and oxides. It would thus seem logical to suspect marked differences in solute movement patterns in the two types of soils. As no data is available on solute movement for soils on the south coast, a preliminary field study on fertilizer solute movement was undertaken in collaboration with the Israeli Puerto Rico Agricultural Corporation (ISPRAC), Santa Isabel.

\section{MATERIALS AND METHODS}

This study was conducted in a commercial tomato (var. Floradel) field at the ISPRAC Farm, Santa Isabel, Puerto Rico. The tomato seedlings were transplanted January 1, 1981. According to Gierbolini (3), the predominant soils in this area are Fraternidad clay (Udic Chromustert; very fine, montmorillonitic, isohyperthermic), associated with San Antón clay loam and Cortada silty clay loam, both classified as Cumulic $\mathrm{Ha}$ plustolls; loamy fine, mixed, isohyperthermic (2). The sum of ammonium acetate extractable cations (table 1) determined at the site prior to the experiment was somewhat low for Fraternidad (9); thus the soil must have been either San Antón or Cortada.

All fertilizer applications were via drip irrigation. The source of $\mathrm{N}$ and $\mathrm{K}$ was $\mathrm{KNO}_{3}$; and $\mathrm{P}$ was applied in the form of $\mathrm{H}_{3} \mathrm{PO}_{4}$. Table 2 gives weekly schedule of $\mathrm{N}, \mathrm{P}$, and $\mathrm{K}$ in $\mathrm{kg} / \mathrm{ha}$ during the crop season. The sources and rates of fertilizer are based on information provided by ISPRAC. Actual amounts of fertilizer solutes delivered at the experimental site were not closely monitored.

The drip irrigation system at the farm was a high pressure type, with dripper spacing of $0.6 \mathrm{~m}$, and a bed spacing of $1.8 \mathrm{~m}$. Six bed sections 33 $\mathrm{m}$ long were chosen from an area roughly $72 \times 100 \mathrm{~m}$ within the main tomato field. Three sections were planted to tomates and the other three were left fallow. The three tomato plots received the same cultural practices as the rest of the field.

Soil samples were taken at $0-20,20-40,40-60$, and $60-80 \mathrm{~cm}$ depths at various locations throughout the sampling area prior to the experiment. On April 15 (at the end of the growing season) 16 soil samples were taken from each of the 6 bed sections. The sampling in each section followed a $4 \times 4$ grid pattern, with four $20 \mathrm{~cm}$ depth increments and four $20 \mathrm{~cm}$ horizontal increments directly below and horizontally perpendicular to an emitter, respectively. The tomato plant was $6 \mathrm{~cm}$ away from the dripper. Each soil sample was air-dried and analyzed for $\mathrm{pH}$, electrical conductivity of a 2:1 water soil extract ratio (which was then multiplied by two to estimate the conductivity of the saturation extract), bicarbonate-extractable $\mathrm{P}$ (Olsen method), and (IN, pH 7.00) ammonium acetate 
TABLE 1.-Chemical analysis of soil prior to fertilization at ISPRAC Farm, Santa Isabel, P.R.

\begin{tabular}{|c|c|c|c|c|c|c|c|c|c|c|c|}
\hline \multirow{2}{*}{$\begin{array}{l}\begin{array}{c}\text { Soil } \\
\text { depth }\end{array} \\
\mathrm{cm}\end{array}$} & \multirow[t]{2}{*}{$\mathrm{pH}$} & \multirow{2}{*}{ mmhos $/ \mathrm{cm}$} & \multirow{2}{*}{$\frac{\mathbf{P}}{p / m}$} & \multicolumn{2}{|c|}{$\mathrm{CA}$} & \multicolumn{2}{|c|}{$\mathrm{Mg}$} & \multicolumn{2}{|c|}{$\mathrm{K}$} & \multicolumn{2}{|c|}{$\mathrm{Na}$} \\
\hline & & & & $p / m$ & $m e q / 100 \mathrm{~g}$ & $p / m$ & $m e q / 100 \mathrm{~g}$ & $p / m$ & $m e q / 100 \mathrm{~g}$ & $p / m$ & meq $/ 100 \mathrm{~g}$ \\
\hline $0-20$ & 8.22 & 0.41 & 9.7 & 3430 & 17.1 & 697 & 5.8 & 361 & 0.93 & 240 & 1.04 \\
\hline $20-40$ & 8.27 & 0.36 & 10.6 & 3724 & 18.6 & 732 & 6.1 & 380 & 0.97 & 280 & 1.22 \\
\hline $40-60$ & 8.25 & 0.37 & 5.7 & 4335 & 21.7 & 761 & 6.3 & 298 & 0.76 & 251 & 1.09 \\
\hline $60-80$ & 8.29 & 0.38 & 0 & 4347 & 21.7 & 735 & 6.1 & 274 & 0.70 & 250 & 1.09 \\
\hline
\end{tabular}


TABLE 2.- Schedule of fertilizer application to the tomato crop at ISPRAC

\begin{tabular}{|c|c|c|c|}
\hline \multirow{2}{*}{ Period } & \multicolumn{3}{|c|}{ Amount of fertilizer applied ( $\mathrm{kg} / \mathrm{ha})$} \\
\hline & $\mathrm{N}$ & $\mathrm{P}$ & $\mathrm{K}$ \\
\hline Jan $7-13$ & 0.63 & 5.00 & 一 \\
\hline Jan $13-16$ & - & 5.75 & 一 \\
\hline Jan $16-22$ & 1.25 & - & 7.50 \\
\hline Jan $22-30$ & 2.50 & - & 10.00 \\
\hline Feb 1-7 & 0.75 & - & 6.25 \\
\hline Feb 7-14 & 1.25 & - & 3.75 \\
\hline Feb $14-21$ & 1.25 & - & 7.50 \\
\hline Feb 21-29 & 1.00 & - & 7.50 \\
\hline March 1-3 & 1.25 & 10.00 & 7.50 \\
\hline March 3-12 & 1.25 & 12.50 & 7.50 \\
\hline March 12-16 & 5.00 & - & 2.50 \\
\hline March $16-30$ & 10.00 & 3.75 & - \\
\hline April 1-7 & 6.25 & 2.50 & 7.50 \\
\hline April 7-14 & 1.25 & 5.00 & 3.75 \\
\hline \multirow{2}{*}{ April 14-21 } & 5.00 & 2.50 & 5.00 \\
\hline & Total $\overline{29.63}$ & $\overline{47.00}$ & $\overline{76.25}$ \\
\hline
\end{tabular}

\begin{tabular}{|c|c|c|c|} 
SDRIPPER & \multicolumn{3}{c}{$20 \times 20 \mathrm{~cm}$} \\
\hline+56 & +8 & +7 & +4 \\
$(+60)$ & $(+17)$ & $(+16)$ & $(+15)$ \\
\hline+28 & +7 & +5 & +10 \\
$(+31)$ & $(+11)$ & $(+12)$ & $(+15)$ \\
\hline+12 & +3 & +5 & +8 \\
$(+15)$ & $(+12)$ & $(+13)$ & $(+14)$ \\
\hline+6 & +8 & +7 & +6 \\
$(+19)$ & $(+13)$ & $(+11)$ & $(+11)$ \\
\hline
\end{tabular}

FIG. 1.-Changes in bicarbonate-extractable $\mathrm{P}$ (in $\mathrm{p} / \mathrm{m}$ ) in: a) tomato plots (numbers without parentheses); and b) fallow plots (numbers in parentheses) at various positions with respect to an emitter during the course of the experiment. Mean of three samples.

extractable $\mathrm{Ca}, \mathrm{Mg}, \mathrm{K}$, and $\mathrm{Na}$. Soils were analyzed at the Commonwealth Department of Agriculture Laboratory, Dorado, Puerto Rico.

\section{RESULTS AND DISCUSSION}

Figures 1, 2, 3, respectively show the changes in levels of bicarbonateextractable $\mathrm{P}, \mathrm{NH}_{4} \mathrm{OAc}$ exchangeable $\mathrm{K}$, and electrical conductivity (EC) in the tomato and fallow plots during the experiment. A positive sign 
indicates an increase for a given parameter, and a negative sign indicates a decrease.

Figures 1 and 2 indicate the greatest increases in $\mathrm{P}$ and $\mathrm{K}$ concentration directly under the emitter, with large increases in both cases. However, the changes in the two elements were somewhat different at greater distances away from the emitter. Figure 2 indicates that, except for the area directly under the emitter, final levels of exchangeable $\mathrm{K}$ in the upper $40 \mathrm{~cm}$ of the fallow plots were not more than $0.2 \mathrm{meq} / 100 \mathrm{~g}$ higher than the original levels, and a slight decrease of $\mathrm{K}(0.1 \mathrm{meq} / 100 \mathrm{~g}$ or less $)$ was observed in the lower $40-80 \mathrm{~cm}$ of the same plots. In plots with tomatoes, exchangeable $\mathrm{K}$ actually decreased slightly throughout the soil

\begin{tabular}{|c|c|c|c|} 
S DRIPPER & \multicolumn{3}{|c}{$20 \times 20 \mathrm{~cm}$ GRIDS } \\
\hline+0.67 & -0.15 & -0.12 & -0.15 \\
$(+1.24)$ & $(+0.05)$ & $(+0.13$ & $(+0.17)$ \\
\hline+0.02 & -0.22 & -0.26 & -0.25 \\
$(+0.26)$ & $(+0.01)$ & $(+0.01$ & $(+0.09$ \\
\hline-0.14 & -0.15 & -0.18 & -0.18 \\
$(-0.03$ & $(-0.06)$ & $(-0.06)$ & $(+0.03)$ \\
\hline-0.14 & -0.17 & -0.17 & -0.16 \\
$(+0.04)$ & $(-0.14)$ & $(-0.06)$ & $(-0.09)$ \\
\hline
\end{tabular}

FrG. 2.-Changes in exchangeable $\mathrm{K}$ (in meq/100g) in: a) tomato plots (numbers without parentheses); and b) fallow plots (numbers in parentheses) at various positions with respect to emitters during the experiment. Mean of three samples.

profile with the exception of the positions directly under the emitter where an increase was observed. In contrast to $\mathrm{K}$, the amount of extractable $\mathrm{P}$ increased throughout the soil profile in plots with and without tomatoes, although the $\mathrm{P}$ concentration increased more in fallow plots.

The apparent ease with which $\mathrm{P}$ was able to move through the soil was rather surprising in view of the high $\mathrm{pH}$ of the soil. Perhaps one explanation is that since the soil was kept continuously moist, any applied P solution moved mainly through macropores and was thus able to travel relatively long distances before being adsorbed by soil particles. The low $\mathrm{pH}$ of the fertilizer solution (a pH of about 2.0 was measured in a sample of irrigation water in the laboratory) could have reduced precipitation 
reactions between $\mathrm{P}$ and $\mathrm{Ca}^{+2}$ in solution. The soil on which the experiment was conducted was high in $\mathrm{Mg}^{+2}$, and groundwater samples from the area have been found to possess considerable amounts of bicarbonate ${ }^{3}$. Brown (1) has found that both $\mathrm{Mg}^{+2}$ and $\mathrm{HCO}_{3}{ }^{-}$in solution can markedly reduce the rate of precipitation of calcium phosphates, which suggests that these ions could have further prolonged the travel distance of fertilizer $\mathrm{P}$ in the experiment.

The low mobility of $\mathrm{K}$ as indicated in this experiment should be accepted with caution. Uptake of $\mathrm{K}$ in the tomato plots could have been large in comparison to the amount of fertilizer $\mathrm{K}$ applied; hence the observed decrease in exchangeable $\mathrm{K}$ levels even though some $\mathrm{K}$ had moved through the soil. Even in the fallow plots the apparent lack of

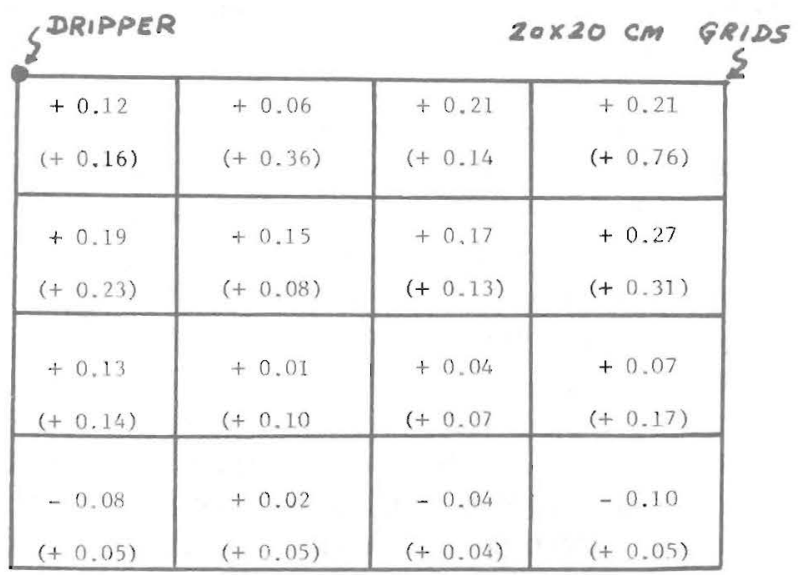

FIG. 3.-Changes in electrical conductivity (in $\mathrm{mmhos} / \mathrm{cm}$ ) in: a) tomato plots (numbers without parentheses); and b) fallow plots (numbers in parentheses) at various positions with respect to emitters during the experiment. Mean of three samples.

significant $\mathrm{K}$ movement could be questionable, since these plots were not cultivated and as a result a considerable amount of grass was allowed to grow. This fact could explain the slight decrease in $\mathrm{K}$ in the lower depths $(40-80 \mathrm{~cm})$ of the soil profile. Both tomatoes and grasses have been known to take up considerably more $\mathrm{K}$ than $\mathrm{P}(6,7,8)$, which could be used as an argument that root uptake in the experiments prevented a $\mathrm{K}$ buildup in the soil while allowing a $\mathrm{P}$ buildup.

Electrical conductivity (fig. 3) increased throughout the soil profile in both the tomato and fallow plots during the experiment, although average increases higher than $0.8 \mathrm{mmhos} / \mathrm{cm}$ were never reached. The greatest

${ }^{3}$ Dr. Raúl Pérez Escolar, personal communication, 1981. 
increases occurred near the soil surface at the point farthest from the emitter, at the salt fringe at the end of the wetting zone near the soil surface. A substantial increase in conductivity was also observed in the vicinity of the emitter, which is consistent with the observed increase of $\mathrm{P}$ and $\mathrm{K}$ in the area. As in the case of $\mathrm{P}$ and $\mathrm{K}$, electrical conductivity values were nearly always higher in the fallow plots than in the tomato plots.

\section{RESUMEN}

Un experimento en una siembra comercial de tomate (var. Floradel) se estableció en la finca ISPRAC (Israeli Puerto Rico Agricultural Corporation) en Santa Isabel, Puerto Rico para investigar los patrones de movimiento del abono aplicado vía riego por goteo. Se establecieron seis parcelas, tres de las cuales se sembraron y las otras tres se dejaron sin sembrar. Se tomaron muestras del suelo a diferentes distancias de la línea de goteo durante la siembra y luego de cada cogida para evaluar su conductividad eléctrica, $\mathrm{pH}, \mathrm{P}$ extractable con bicarbonato, y $\mathrm{Ca}, \mathrm{Mg}$, $\mathrm{K}$ y Na extractables con $\mathrm{NH}_{4} \mathrm{OAC}$ (INa, pH 7). Los abonos aplicados vía riego por goteo fueron $\mathrm{H}_{3} \mathrm{PO}_{4}$ y $\mathrm{KNO}_{3}$. Se observó un movimiento considerable de $\mathrm{P}$ a través del perfil, atribuido en parte a la precipitación lenta de fosfatos cálcicos debido al $\mathrm{pH}$ bajo del agua de riego y la posible presencia de $\mathrm{Mg}^{+2}$ y $\mathrm{HCO}_{3}{ }^{-}$en solución, y también al movimiento predominante de la solución fertilizante a través de los macroporos del suelo. El movimiento de $\mathrm{K}$ fue menos evidente que en el caso del $\mathrm{P}$, pero un mayor movimiento pudo haber sido enmascarado por altos niveles de absorción del $\mathrm{K}$ por el sistema radical de la tomatera. Los aumentos en conductividad eléctrica fueron mayores cerca del gotero y a lo largo de la zona de acumulación de sales al borde de la región humedecida del suelo cerca de la superficie. Los aumentos en conductividad fueron más altos en esta última zona, pero nunca excedieron $0.8 \mathrm{mmhos} / \mathrm{cm}$. Los niveles de $\mathrm{P}, \mathrm{K}$ y conductividad eléctrica casi siempre fueron mayores en las parcelas sin sembrar que en las sembradas, probablemente debido a la absorción de nutrimentos por las plantas.

\section{LITERATURE CITED}

1. Brown, J. L., 1981. Calcium phosphate precipitation: effects of common and foreign ions on hydroxyapatite crystal growth, Soil Sci. Soc. Am. J. 45: 482-86.

2. Fox, R. L., 1982. Some highly weathered soils of Puerto Rico, 3. Chemical properties. Geoderma 27: 139-176.

3. Gierbolini, R. F., 1979. Soil Survey of the Ponce Area of Southern Puerto Rico, USDASCS in coop. with the Univ. of P. R. Coll of Agric. Sci.

4. Jones, R. C., W. H. Hudnall and W. S. Sakai, 1982. Some highly weathered soils of Puerto Rico, 2. Mineralogy, Geoderma 27: 75-137. 
5. Keng, J. C. W., 1978. Water and Nutrient Management with Drip Irrigation in Highly Weathered Soils of the Tropics, Ph.D. Thesis, Cornell University.

6. Lorenz, O. A. and M. T. Vittum, 1980. Phosphorus nutrition of vegetable crops and sugar beets, In "The Role of Phosphorous in Agriculture", Am. Soc. Agron. Page 756.

7. Lucas, R. E., 1968. Potassium nutrition of vegetable crops, In "The Role of Potassium in Agriculture," Am. Soc. Agron., Pages 489-97.

8. Sánchez, P. A., 1976. Properties and Management of Soils in the Tropics, WileyInterscience. Pages 200-203.

9. Soil Survey Staff, 1967. Soil Survey Laboratory Data and Descriptions for some Soils of Puerto Rico and the Virgin Islands. USDA-SCS in coop. with P. R. Agric. Exp. Stn., Soil Survey Inv. Rep. No. 12. Page 191. 